\title{
Seroprevalence of hepatitis $C$ virus markers in multi-transfused children with beta-thalassemia
}

\author{
Kiran Madhusudhan ${ }^{1 *}$, SP Thyagarajan ${ }^{2}$ \\ From First International Science Symposium on HIV and Infectious Diseases (HIV SCIENCE 2012) \\ Chennai, India. 20-22 January 2012
}

\section{Background}

To study the seroprevalence of hepatitis $C$ virus in multi-transfused children with $\beta$-thalassemia and compared with non transfused children and healthy controls. $\beta$-thalassemic children fail to thrive, with growth and developmental retardation and suffer microcytic hypochromic anemia. Since regular blood transfusions are given to maintain haemoglobin at a safe level, these children are at a high risk of acquiring hepatitis $C$ virus through transfusions.

\section{Methods}

Study group, consisted of children 2-13 years with $\beta$-thalassemia and received more than 5 transfusions. Matched control group consisted of 30 children with $\beta$-thalassemia and no transfusion. Control group, consisted of 30 normal healthy children serum samples from all three groups were tested for antibodies to hepatitis $C$ virus using commercial ELISA kits.

\section{Results}

Study showed $32 \%$ anti $\mathrm{H}$ hepatitis $\mathrm{C}$ virus positivity in multi-transfused and $0 \%$ in matched and healthy control groups. Hepatitis $\mathrm{C}$ virus infection showed a significant increase in relation to the number of transfusions received.

\section{Conclusion}

This observation is of great concern, as these children are at a risk of developing chronic hepatitis, cirrhosis and hepatocellular carcinoma. Since vaccination against hepatitis $C$ virus is not available, highly sensitive and specific screening methods of donor blood in blood banks must be made mandatory.

\footnotetext{
* Correspondence: brskiran@yahoo.in

${ }^{1}$ Shree Balaji Medical College \& Hospital, Chennai, India

Full list of author information is available at the end of the article
}

\author{
Author details \\ 'Shree Balaji Medical College \& Hospital, Chennai, India. ${ }^{2}$ Sri Ramachandra \\ Medical College \& Research Institute, Chennai, India.
}

Published: 4 May 2012

doi:10.1186/1471-2334-12-S1-P42

Cite this article as: Madhusudhan and Thyagarajan: Seroprevalence of

hepatitis $C$ virus markers in multi-transfused children with beta-

thalassemia. BMC Infectious Diseases 2012 12(Suppl 1):P42.
Submit your next manuscript to BioMed Central and take full advantage of:

- Convenient online submission

- Thorough peer review

- No space constraints or color figure charges

- Immediate publication on acceptance

- Inclusion in PubMed, CAS, Scopus and Google Scholar

- Research which is freely available for redistribution

Submit your manuscript at www.biomedcentral.com/submit

\section{() Biomed Central}

